\title{
Novel Nonsense p.C522X Mutation in SLC5A2 Gene of a Turkish Family with Familial Renal Glucosuria: A Molecular Case Report
}

\author{
Afig Berdeli ${ }^{*}$, Sinem Nalbantoglu ${ }^{3}$, Sevgi Mir ${ }^{2}$, Fatma Mutlubas Ozsan², Sırrı F. Cam ${ }^{4}$ and Mustafa Solak \\ ${ }^{1}$ Ege University Faculty Of Medicine Department Of Pediatrics Child Hospital Molecular Medicine Laboratory, Bornova, Izmir, Turkey \\ ${ }^{2}$ Ege University Faculty Of Medicine Department Of Pediatrics Division Of Pediatric Nephrology Bornova, Izmir, Turkey \\ ${ }^{3}$ Ege University Faculty Of Medicine Department Of Pediatrics Molecular Medicine Laboratory Bornova, Izmir, Turkey \\ ${ }^{4}$ Celal Bayar University Faculty Of Medicine Department Of Medical Genetics Manisa, Izmir, Turkey \\ ${ }^{5}$ Afyon Karahisar University Faculty Of Medicine Department Of Medical Genetics Afyon, Turkey
}

\begin{abstract}
Background: Familial renal glucosuria $(F R G)$ is a rare renal tubular disorder which has recently been shown to result from mutations in SLC5A2 gene, encoding the kidney-specific low-affinity/high-capacity Na+/glucose cotransporter protein, SGLT2. The vast majority of FRG cases were shown with the confirmation of SLC5A2 mutations with larger numbers of samples from various groups. Here we present a Turkish family of mild glucosuria, with nonsense $p$.C522X mutation in SLC5A2 gene.
\end{abstract}

Methods: DNA Sequencing analysis was performed for all the affected probands and the unaffected individuals.

Results: Except for the father, the children and the mother were found out to have p.C522X mutation in SLC5A2 gene together with the divergent clinical implications.

Conclusions: Rather it was found to be a sample of recessive or dominant type of renal glucosuria, the case indicated here was suggested as a model for autosomal co-dominant trait with complete penetrance and variable expressivity.

Keywords: Familial Renal Glucosuria (FRG); SLC5A2; Nonsense mutation; DNA cycle sequencing

\section{Introduction}

Renal glucosuria (OMIM233100) is a proximal tubular glucose transport disorder causing abnormal urinary glucose excretion with normal blood glucose levels and without proximal tubular dysfunction or morphological renal anomalies. Glucose is filtered from the blood at the glomerulus and then reabsorbed in the S1 segment of the proximal tubule via specific apical glucose transporters in kidney, the central regulators of plasma glucose levels [1]. If the filtered amount of glucose increases, glucose reabsorption reaches saturation. After passing the threshold when transporters fully saturate, the amount of reabsorbed glucose does not increase, and excretes in the urine; finally degredation of normal conditions comes out [2].

Familial renal glucosuria (FRG) (OMIM 233100) is found out to be a rare renal tubular disorder caused by mutations within the $S L C 5 A 2$ gene, the $\mathrm{Na}+$ /glucose cotransporter family [3,4]. Renal glucose reabsorption is mediated by luminal $\mathrm{Na}+$ /glucose cotransporters (SGLTS) and basolateral facilitative glucose transporters (GLUTs) in epithelial cells lining the jejunum and proximal renal tubules, which are $\mathrm{Na}+$ /glucose cotransporters concentrating glucose inside cells using the transmembrane electrochemical potential of $\mathrm{Na}+[5]$. To date, several nucleotide changes were shown in this gene to cause FRG. Here we report a Turkish family with an inherited novel nonsense mutation in SLC5A2 gene (p.C522X) clinically thought to cause FRG.

\section{Materials and Methods}

\section{General criteria}

The study was approved by the Ethical Committee of Ege University Faculty of Medicine. Probands were informed about the study and signed (by the patient or by his/her parent) an informed consent according to the recommendations of the declaration of Helsinki for investigation with human subjects.

\section{Patients and control subjects}

A Turkish family with two children having suspicious renal glucosuria diagnosis and 50 chromosomes from 25 healthy individuals were enrolled into the study. None of the control subjects had any signs of a generalized tubular dysfunction or of any other type of renal disease. Urinary glucose concentration was repeatedly determined by dipstick before it was quantified by the glucose oxidase method in aliquots of 24-h urine collected on a free diet in which normal range was accepted as 0.13 to $0.32 \mathrm{~g} / 1.73 \mathrm{~m}^{2}$ per $\mathrm{d}[0.72$ to 1.8 $\mathrm{mmol} / 1.73 \mathrm{~m}^{2}$ per $\left.\mathrm{d}\right][6]$.

\section{Genomic DNA preparation and quantitation}

Genomic DNA (gDNA) from $2 \mathrm{ml}$ of peripheral blood samples which were collected into ethylenediaminetetraacetic acid (EDTA)anticoagulated tubes by the standard venipuncture method was extracted using the QIAmp blood DNA Isolation kit following manufacturer's instructions. DNA concentration was determined by using Thermo Scientific Nanodrop apparatus.

${ }^{*}$ Corresponding author: Prof. Afig Berdeli, MD, PhD, Ege University Faculty O Medicine Department Of Pediatrics Child Hospital Molecular Medicine Laboratory Bornova, İmir, Turkey, Tel: +09 532 7776200; Fax: +902322537682; E-mail: afigberdeli@yahoo.com

Accepted November 16, 2010; Published November 19, 2010

Citation: Berdeli A, Nalbantoglu S, Mir S, Ozsan FM, Cam SF, et al. (2010) Nove Nonsense p.C522X Mutation in SLC5A2 Gene of a Turkish Family with Familia Renal Glucosuria: A Molecular Case Report. J Cytol Histol 1:104. doi:10.4172/21577099.1000104

Copyright: ( 2010 Berdeli A, et al. This is an open-access article distributed unde the terms of the Creative Commons Attribution License, which permits unrestricted use, distribution, and reproduction in any medium, provided the original author and source are credited. 


\begin{tabular}{|c|c|c|c|c|c|c|c|c|c|c|c|c|c|}
\hline Case & $\mathrm{Ph}$ & Density & Osmolality & Glucose & Protein & Microscoby & $\begin{array}{l}24 \text { hour Urine } \\
\text { volume }\end{array}$ & \begin{tabular}{|l|}
24 \\
protein
\end{tabular} & TPR & FENa & FEK & $\mathrm{Ca} / \mathrm{Cr}$ & Ca excretion \\
\hline & & & Mosm/L & mg/dl & mg/dl & & $\mathrm{ml} / \mathrm{d}$ & $\mathrm{mg} / \mathrm{m}^{2} / \mathrm{h}$ & & & & & $\mathrm{mg} / \mathrm{kg} / \mathrm{d}$ \\
\hline Patient 1 & 6.5 & 1015 & 967 & 1000 & Negative & Normal & 1100 & 2.1 & 92 & 0.4 & 2.4 & 0.16 & 2.1 \\
\hline Patient 2 & 6 & 1010 & 804 & 1000 & Negative & Normal & Spot & 0.18 & 95 & 0.2 & 5.7 & 0.18 & ND \\
\hline Mother & 5 & 1030 & 862 & 300 & Negative & Normal & 1500 & 2.5 & 94 & 0.6 & 4 & 0.09 & 0.8 \\
\hline Father & 5 & 1025 & 922 & 0 & Negative & Normal & 1200 & 1.2 & 91 & 0.4 & 3.2 & 0.12 & 1.2 \\
\hline
\end{tabular}

Table 1: Demografic features of the probands showing tubulary function analysis.

\begin{tabular}{|c|c|c|c|c|c|c|c|}
\hline $\begin{array}{l}\text { Family } \\
\text { member }\end{array}$ & $\begin{array}{l}\text { Glucose excretion } \\
(\mathrm{g} / 1.73 \mathrm{~m} 2 / 24 \mathrm{~h})\end{array}$ & Region & $\begin{array}{l}\text { Nucleotide } \\
\text { Change; Allele } 1\end{array}$ & $\begin{array}{l}\text { Nucleotide } \\
\text { Change; Allele } 2\end{array}$ & $\begin{array}{l}\text { Mutation } \\
\text { State }\end{array}$ & $\begin{array}{l}\text { Mutation } \\
\text { Type }\end{array}$ & $\begin{array}{l}\text { Amino Acid } \\
\text { change }\end{array}$ \\
\hline Patient 1 & 5.8 & Exon 12 & $\begin{array}{l}\text { c. } 1566 C>A \\
\text { (TGC/TGA) }\end{array}$ & Wt & Heterozygous & Nonsense & p.C522X \\
\hline Patient 2 & 5.2 & Exon 12 & $\begin{array}{l}\text { c. } 1566 C>A \\
(T G C / T G A)\end{array}$ & Wt & Heterozygous & Nonsense & p.C522X \\
\hline Mother & 2.0 & Exon 12 & $\begin{array}{l}\text { c.1566C>A } \\
(T G C / T G A)\end{array}$ & Wt & Heterozygous & Nonsense & p.C522X \\
\hline Father & 0.11 & Exon 12 & $\mathrm{Wt}$ & Wt & - & - & - \\
\hline
\end{tabular}

Table 2: Mutation analysis and glucose excretion in affected individuals.

\section{Molecular analysis}

Polymerase chain reaction and DNA sequencing analysis: Molecular analysis was carried out on genomic DNA extracted from EDTA anticoagulated venous blood using QiAamp DNA Blood Mini kit (QIAGEN GmbH, Hilden Germany) according to manufacturer's instructions. The diagnostic strategy was based on screening the 14 entire coding exons and adjacent intronic segments of SLC5A2 gene. For the studied SLC5A2 gene, the genbank data were as follows: NCBI Reference Sequence NG_012892.1 RefSeqGene; NC_000016.9: (NM 003041.3; NP 003032.1); definition, homo sapiens SLC5A2 (solute carrier family 5 (sodium/glucose cotransporter), member 2unique isoform; $2279 \mathrm{bp}$ mRNA and 672 amino acid sequence lenght. All 14 exons of SLC5A2 gene were amplified by polymerase chain reaction (PCR) using flanking intronic primers, designed by ExonPrimer programme. All synthetic oligonucleotide primers synthesized and purchased by Invitrogen Ltd. (Paisley, UK) as the HPLC purification grade (primer sequences are available upon request).

PCR amplification reactions were performed using $100 \mathrm{ng}$ of human gDNA. PCR amplification was carried out on Corbett PalmCycler gradient thermal cycler (Corbett Life Science, Australia) in a $25 \mu \mathrm{l}$ reaction mixture in $0.2 \mathrm{ml}$ thin-wall PCR strip tubes containing $1 \mu \mathrm{l}$ genomic DNA solution, 1.0 U Platinium TAQ with Enhancer Buffer (Invitrogen Ltd. Paisley, UK), 50 $\mathrm{mol} / \mathrm{l}$ each of the dGTP, dATP, dTTP and dCTP, 5 pmol each forward and reverse primers. The cycling conditions comprised a hot start at $95^{\circ} \mathrm{C}$ for $10 \mathrm{~min}$, followed by 35 amplification cycles at gradient programme. Before cycle sequencing reactions, the amplified PCR products were purified using ExoSap-IT PCR purification Kit (Amersham Life Scince, USB). Cycle sequencing PCR was performed with BigDye Terminator v.3.1 kit as manufacturer's instructions. Cycle sequencing PCR products, after purification with BigDyeXT Terminator kit, were analyzed in ABI 3100 Genetic Analyser System. DNA sequencing was performed bidirectionally. For sequence evaluation, SeqScape 2.0 sequencing analysis software was used.

\section{Results}

\section{Case report and clinical characterization}

The 4.5-year-old girl (the first child of the family) was taken to Child Hospital at Ege University School of Medicine by her family for routine control. Detailed urine tests were performed in either spot urine or $24 \mathrm{~h}$ collected urine analysis (Table 1, Table 2). Her urine dipstick analysis showed $1000 \mathrm{mg} / \mathrm{dl}$ glucose and $24 \mathrm{~h}$ glucose excretion was $5.8 \mathrm{~g} / 1.73 \mathrm{~m}^{2} / 24 \mathrm{~h}$ without other anomalies in urine. She was in normal growth and percentiles (weight: $15.5 \mathrm{~kg}$ and, height: $107 \mathrm{~cm}$ ). Mental development was in normal limits. She had no any active complaints and no determined allergy. She had normal blood biochemistry results including normal blood glucose levels of $96 \mathrm{mg} / \mathrm{dL}$. Polyuria, polydipsia and proteinuria were not seen. Kidney function tests, phosphate, protein creatine, absorption of free amino acids and urine acidification with carbohydrate metabolism, storage, usage and insulin secretion were all normal. None of them had any pathology related to kidney function diagnosis with the exception of glucosuria. It was confirmed that the excreted sugar was glucose excluding pentosuria, fructosuria, sucrosuria, maltosuria, galactosuria, and lactosuria (the renal abnormality is specific to only glucose, not to other monosaccharides). Relative to assessment of osteomyelitis and growth retardation which this mutation accompany with, Vit-D and PTH have been searched and normal line clinical evidence was determined. Bone age of the case was in accordance with the chronological age. With normal USG assessment of the case, polyclinic observation has been decided. There was no tubular disfunction according to tubulary tests including FENa, FEK, TPR, and urine concentration. $\mathrm{Ca} / \mathrm{Cr}$ ratio and urine protein levels were found to be in normal ranges (Table 1). Endocrinological profiles including Hemoglobine $\mathrm{A}_{1} \mathrm{C}$, parathormone, thyroid fuction tests, and VitD were also in normal ranges. She was accepted as renal glucosuria. Other family members including the ten-months-old sister, mother, and father were examined. Her mother and ten-months-old sister were also found to have glucosuria in levels of $300 \mathrm{mg} / \mathrm{dl}$ and 1000 $\mathrm{mg} / \mathrm{dl}$, and $24 \mathrm{~h}$ glucose excretions were 2.0 and $5.2 \mathrm{~g} / 1.73 \mathrm{~m}^{2} / 24 \mathrm{~h}$, respectively. Father's urine analysis showed no glucosuria.

\section{Results of molecular analysis}

Mutation analysis in the 4.5-year-old proband revealed a novel $1566 \mathrm{C}>\mathrm{A}$ heterozygous sequence change in exon 12 of SLC5A2 gene (TGC/TGA), resulting in stop codon at position 522 of SGLT2 amino acid sequence (p.C522X) (Figure 1, Figure 2 and Figure 3). Following this result, the sister, father, and mother had taken to mutation screening of SLC5A2 gene by DNA sequencing analysis system. C522X nonsense mutation was found in the mother and the sister, and the father did not have the mutation.

In the DNA sequencing analysis, the heterozygous mutation (TGC $\rightarrow$ TGA; C to A transition at position 1566) was not identified in 50 control chromosomes. The identified mutation, p.C522X, is a nonsense truncating mutation that would cause premature 


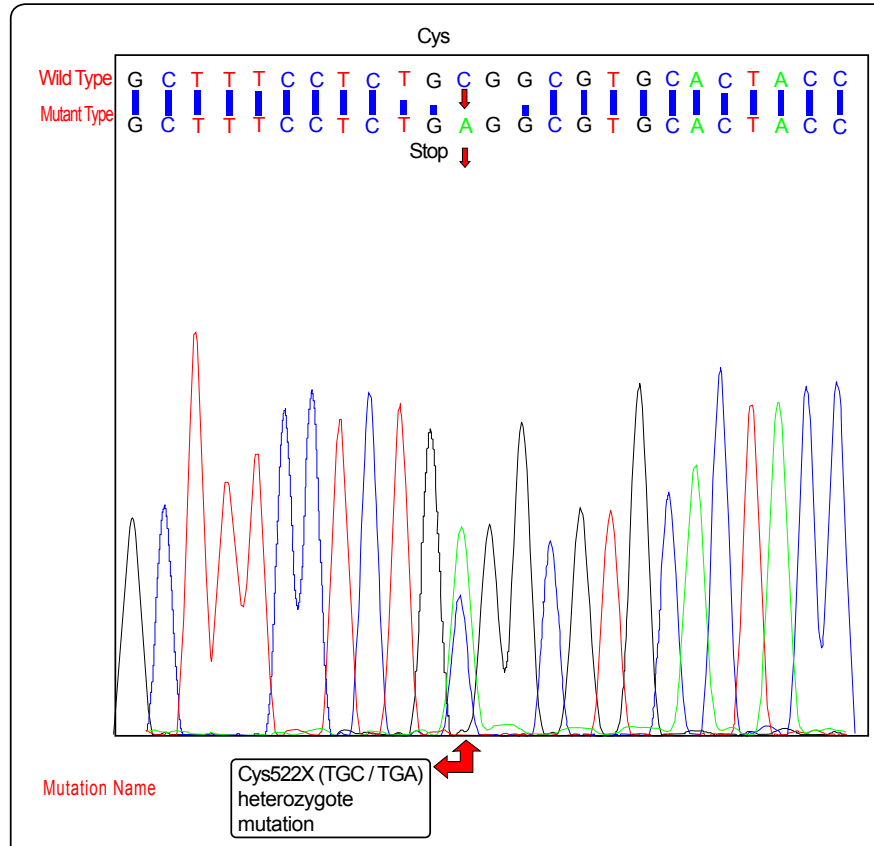

Figure 1: Electropherogram for a novel c.1566C>A heterozygous nucleotide substitution in exon 12 of SLC5A2 gene (TGC/TGA), resulting in a stop codon at position 522 of $S G L T 2$ amino acid sequence (p.C522X).

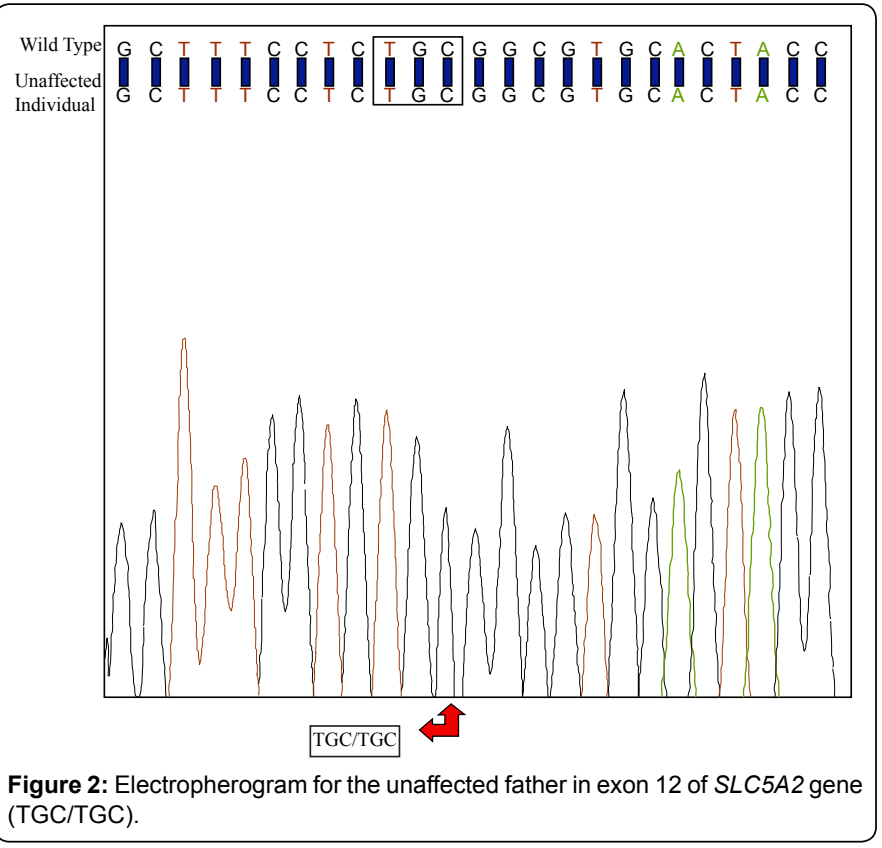

termination of translation. This would result in a truncated SGLT2 protein lacking the last 150 amino acids which was localized close to the carboxyl terminus of the protein.

\section{Discussion}

Familial renal glucosuria (FRG, McKusick 233100) is an inherited disorder of proximal tubular glucose transport characterized by persistent glucosuria in the presence of normal serum glucose concentration and absence of any tubular nonfunctionality. Santer et al reported the major candidate gene SLC5A2 for FRG, chromosomally located in 16p12-p11 which has 14 exons and a unique transcript of 672 amino acid sequence length encoding the low affinity sodium glucose cotransporter SGLT2 protein [7]. Subsequently, the vast majority of FRG cases were shown with the confirmation of SLC5A2 mutations in varios exons of the gene and from various groups [712]. To date, in renal glucosuria patients, mutations belonging to exon 12 had first been reported by Calado et al. [13] including also nonsense mutations. In a case report of Van den Heuvel et al. [12], a Turkish patient with congenital isolated renal glucosuria having a homozygous nonsense mutation in exon 11 of the SLC5A2 gene leading to the formation of a truncated cotransporter has been reported. In that study, both parents and the brother of the child, all three without renal glucosuria, were heterozygous for the nonsense mutation. Heterozygous individuals were reported to have only mild glucose excretion (2.7-6.5 g/1.73 $\mathrm{m}^{2} / 24 \mathrm{~h}$ ) whereas homozygous or compound heterozygous patients had severe glucosuria ranging from 10 to $86.5 \mathrm{~g} / 1.73 \mathrm{~m}^{2} / 24 \mathrm{~h}$. Mutation analysis in the probands of our study revealed a novel heterozygote nonsense mutation in exon 12 of SLC5A2 gene (TGC/TGA) at the position of 1566 cDNA resulting in p.C522X nonsense mutation which was not found in the 50 healthy Turkish alleles. For the probands in this study, thought as mild glucosuria, the amount of glucose excreted ranged from 2.0 to 5.8 $\mathrm{g} / 1.73 \mathrm{~m}^{2} / 24 \mathrm{~h}$, reflecting the heterozygous character of the mutation. Since the cases presented here were seen as mild glucosuria, basal plasma renin activity and serum aldosterone concentrations were not determined.

In this study, although the mother and the two daughters share the same nonsense mutation, their clinical implications had some obvious differences relative to glucose levels. The clinical divergent implications seen in the family members brought some challenge with the autosomal recessive inheritence pattern of the disease. Also, in Calado's report, one case having heterozygous p.N654S sequence variation, referred to as a polymorphism, reported as having mild glucosuria [13]. In this case, rather it was found to be a sample of recessive or dominant type of renal glucosuria, the case indicated here was seen as an autosomal co-dominant trait with complete penetrance and variable expressivity. Besides, it may be thought that a polygenic inheritance pattern (involving other genetic or nongenetic factorsenviromental, physical or social factors, sample size of patients, molecular genetic analysis procedure, involvement of noncoding regions as well as the coding regions in the molecular analysis) can be seen in renal glucosuria with the contribution of relative modifying genes leading genetic heterogeneity in the disorder. Modifier genes, other possible sodium glucose co-transporter members of SLC5 family comprising over 230 members involving 11 members of the human genome, may have a role in defining the particular phenotype and account for the incomplete penetrance defined in FRG. Genetic heterogeneity may be caused by other cotransporters which may

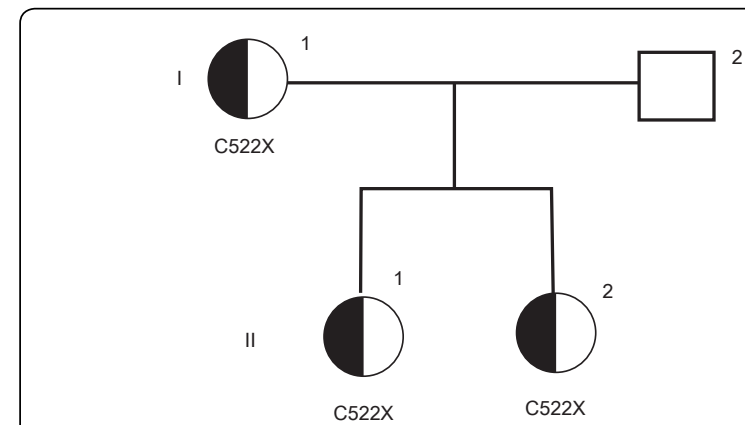

Figure 3: Pedigree demonstrating the affected probands who have p.C522X heterozygous mutation in the family. 
be entitled as modifier genes that constitutes the incomplete penetrance seen in FRG. The results of this study are in accordance with earlier clinical and molecular observartions dealing with the inheritance pattern that heterozygous mutations are associated with mild glucosuria $\left(2,7-6,5 \mathrm{~g} / 1.73 \mathrm{~m}^{2} / 24 \mathrm{~h}\right)$. Despite the significant role of SLC5A2, other genes may be involved in renal glucose transport to varying degrees and may be mutated in patients with renal glucosuria. Especially in family case reports of hereditary disorders, the divergence of the phenotype strongly suggest the impact of other genes in occurrence of the current disease. Possible mechanisms for the unexplained transcriptional regulation of SGLTS and the genetic heterogeneity seen in FRG caused by the presence other genes and modifier genes. For $S G L T 1$, role of protein kinases were shown, and suggested that sequence differences in SGLTs could effect the regulation of trafficking by protein kinases [14]. Five transcription factors (HNF-1 alpha, HNF-1 beta, HNF-4alpha, IPF-1, and NEURO-D1) produce different forms of diabetes [15-17], and a defect of HNF-1 $\alpha$ cause maturity-onset diabetes in the young type 3, with diminished renal threshold for glucose, which was not present in the probands of this study. Also, hepatic nuclear factor (HNF)- $1 \alpha$ was found out to regulate the transcription of mouse SGLT2 [18], and for human $S G L T 1$, critical role for the HNF-1 and Sp1 (specificity protein 1) multigene members in enhancing the basal level of its transcription (the binding domain for this transcription factor) in Caco-2 cells was reported [19]. Kekuda et al. [20] reported that Sp1 together with HNF1 transcription factor regulate SGLT1 transcription in the chronically inflamed intestine. Also, Tabatabai et al. [21] showed diabetes related changes in mRNA expressions of kidney glucose transporters SGLT1 and 2 in zucker rats. Furthermore, mutations in other genes, having strong genetic linkage as shown for the HLA locus and GLYS1 in renal glycosuria [22], and the entire members of SGLT and GLUT family should be considered as possible candidates.

Regarding the reported high similarity of the primary sequences and secondary structure of SGLT1 and SGLT2, Santer et al. [7] showed $58 \%$ amino acid identity between $S G L T 1$ and $S G L T 2$ protein, and a higher degree of homology was also observed in central domains of the polypeptide. Though there is little information available about SGLT2 due to its low level of expression, the general secondary structure model shows 14 transmembrane helices (TMH) with both the $\mathrm{NH} 2$ and $\mathrm{COOH}$ termini facing the extracellular region [23]. Panayotova-Heiermann et al. [24] reported that while sugar-binding/ translocation to $\mathrm{Na}+$ /glucose cotransporters was determined by the $\mathrm{COOH}$-terminal domain (sugar affinity and selectivity; residues 407-662 containing TMHs 10-14, referred to as $\mathrm{C5}$ ), $\mathrm{Na}+$ binding/ coupling is determined by the NH2-terminal domain of the protein, and conformational change in the protein allowing sugar binding and translocation occurs. TMH 5 and 6 were shown in $8 \AA$ of TMH 10-11 [25]. In the expression studies of the same group, truncated protein containing residues 407-662 (C5) were shown as a sugar uniporter [26,27]. However, in 2001, Wright et al. [28] reported that deletion or missing of TMH 14 did not disturb sugar transport, meaning only TMHs $10-13$ lie in close proximity constituting the sugar translocation pathway through SGLT1. It was reported that in SGLTS amino terminus (residues 1-27), two hydrophilic loops located in the center (residues 229-271), and the carboxyl terminus (residues 548-644) constitute the nonconserved polar residues, and posibly responsible for the charge movement and/or substrate specificity differences. Panayotova-Heiermann et al. [24] reported that recognition/transport domain of organic substrate is mediated by interactions distal to amino acid 380 , while cation binding is determined by interactions arising from the amino- and carboxyl- terminal halves of the transporters, and found out the largest loop between M13/M14 involving most of the differently charged amino acid substitutions any of which could contribute to the organic substrate binding.

SGLT2 nonsense, frameshift, and missense mutations are predicted to result in disturbed affinity for the spesific substrate due to the absence of transmembranous domains 10 to 13 essential for sugar binding/transport, (when the 14th helix deleted, only four helices, 10-13, were sufficient for sugar transport pathway), and thus leading to mild glucosuria [27]. In Santer et al. [11] study, patient with P324fs347X homozygous mutation leading to a truncating protein, and predicted to have only the seven $\mathrm{N}$-terminally located transmembranous domains without the missing TMH 8-14 domains demonstrated a daily glucose excretion in excess of $100 \mathrm{~g} / 1.73$ $\mathrm{m} 2$ per $\mathrm{d}$. Obviously, it was a nonfunctional glucose transporter underscoring the lack of glucose reabsorption due to the absence of the transmembranous domains 10 to 13 which were postulated to have a role for sugar binding/ translocation $[24,26,28]$. Interestingly, another patient in that study with homozygous W440X nonsense truncating mutation showed lower glucose excretion $(68.7 \mathrm{~g} / 1.73 \mathrm{~m} 2$ per $\mathrm{d}$;), there was a challenge and suggested alternative mechanisms for glucose reabsorption. The same group also documented that all heterozygous individuals had not increased glucose excretion, and only some had mild glucosuria, suggesting a place for possible genetic or nongenetic factors to be present accompanying the heterozygous SGLT2 mutations which were expected to result in mild glucosuria. Therefore it would be more convenient to suggest a codominant trait with expressivity.

Directed mutagenesis studies provided the identification of amino acid residues important for substrate and inhibitor binding. In Wright's study, a compound heterozygous patient (SGLT1 R499Hhelix 12/R379X) with glucose-galactose malabsorption was shown with severe clinical course, and this mutant was demonstrated to result in a significant decrease of sugar affinity and trafficking to the membrane in the functional expression studies performed in oocytes. The replacing of this residue with cysteine was suggested to result in restored trafficking and functional sugar transport [29]. Steel and Hediger [30] studied A304V and R499H-helix 12 mutations and determined impaired trafficking of the cotransporters to the plasma membrane, as in accordance with the results of Martin et al. [31] who suggested a role for polar and charged residues in the retention of protein conformation due to electrostatic interactions. Also, SGLT1 R427A mutation was shown in membrane targeting due to the accumulation of the mutant protein beneath the membrane surface. Since, Q457A-helix 11 showed reduced sugar transport and $\mathrm{R} 499 \mathrm{H}$ was along with an increase in $\mathrm{Km}$, these residues were thought to lie close to the sugar binding site (COOH). SGLT1 N176A was reported to effect only the presteady state kinetics and not the sugar-induced steady state [32]. K321A-helix 7 mutants decreased the affinity for $\mathrm{Na}+$ ions, without changes in sugar affinity (only secondary effects on sugar binding to the protein) [33]. N176A and K321A were located in the amino-terminal half of SGLT1 and did not substantially effect sugar binding, in contrary to R499H, found out in a glucose/galactose malabsorption patient, which was localized close to the carboxyl terminus of the protein [31], and proved a decrease in the apparent affinity for sugar without affecting $\mathrm{Na}+$. Althoff et al. [34] reported Thr/459 and Ser/460 in the SGLT from shark located in transmembrane helix 11 indicating sugar translocation pathway [26]. Kasch [35] found Cys351 and Cys361 (SGLT1 and SGLT2) in the extracellular loop 8 defining sugar affinity of the transporter. 
Citation: Berdeli A, Nalbantoglu S, Mir S, Ozsan FM, Cam SF, et al. (2010) Novel Nonsense p.C522X Mutation in SLC5A2 Gene of a Turkish Family with Familial Renal Glucosuria: A Molecular Case Report. J Cytol Histol 1:104. doi:10.4172/2157-7099.1000104

Page 5 of 6

Wright [36] described p.Q167fsX186 mutation leading to a truncated protein in the absence of the last $505 \mathrm{C}$-terminal amino acids, the region that contains the consensus $\mathrm{N}$-linked glucosylation sites and transmembrane domains 10-13, lacks the sugar translocation path. Lostao et al. [37] described reduced trafficking and amount of C5 molecules in the plasma membrane because of a single residue (R427A) in SGLT1. According to these previous reports, when considering the highly identical membrane topology of SGLT1 with SGLT2, p.C522X nonsense truncating mutation are predicted to locate in the extracellular loop 13 and C5 (amino acids 407-672, helices 10-13) lying in close proximity to the sugar binding site $(\mathrm{COOH})$, and lacking the last 150 amino acids/helix 14/TMH13-14, and are thought to effect sugar affinity (without any effect on $\mathrm{Na}+$ ) and trafficking of the SGLT2 transporter. It was reported that TMH10-13 were important for sugar affinity except for TMH14. In this study, it is obvious from the daily glucose excretions in the probands that the absence of TMH13 without 10,11 , and 12 , was sufficent to give the evidence of typical isolated renal glucosuria phenotype. However, the arguement that a mutation affects a highly conserved functionally important region of a gene/protein is not very relevant in the case of a nonsense mutation. Truncation of the protein, will lead to loss of other regions distal to the mutation. According to above previous reports, missense and nonsense SLC5 mutations leads to disorder because of the missing expression of such proteins within the cell membrane, and the problem is not the functional loss. Furthermore, analysis of this newly found mutation, in order to evaluate the potential pathogenicity, was not carried out by the PolyPhen software [38] because it was already a nonsense mutation whose pathogenic significance is obvious and predicted to be possibly damaging. However, in FRG, future studies are required to confirm critical domain functions of $S G L T 2$ which is currently a drug target for the treatment of type II diabetes [39].

Nevertheless, great sequence and structure homology of SGLTs were reported and it can be surely thought that disturbed trafficking shown to play a major role not only for SGLT1 mutations but also for SGLT2 [31]. In this study, we were not able to perform expression patterns of SGLT2 mutations. However, human SGLT2 expression in heterologous systems, unlike SGLT1 and SGLT3, was reported to be very poor in oocytes and COS-7 cells $[36,40]$. Santer et al. [7] expression studies worked on Xenopus laevis oocytes and in isolated vesicles with perfect expression patterns with SGLT1 and other transporters, but not with $S G L T 2$. So, the mechanism is not yet obvious for $S G L T 2$ mutations in the impairment of glucose transport.

In conclusion, this data is the first direct evidence of an etiologic role for the sodium/glucose cotransporter type 2 in the pathogenesis of renal glucosuria in a Turkish family. The detection of certain SGLT2 mutations predicted to be nonfunctional correlates with the lack of glucose reabsorption and proves the critical requirement for SGLT2 in renal tubular glucose transport.

\section{Acknowledgements}

We thank the family members who participated in this study.

\section{References}

1. Brodehl J (1992) Renal glucosuria. Pediatric Kidney Disease In: Edelman CM (ed) Second edition Volume II; Boston, Toronto, London; Little, Brown, and Company Inc; 1801-1810.

2. Calado J, Soto K, Clemente C, Correia P, Rueff J (2004) Novel compound heterozygous mutations in SLC5A2 are responsible for autosomal recessive renal glucosuria. Hum Genet 114: 314-316.

3. Vestri S, Okamoto MM, de Freitas HS, Aparecida Dos Santos R, Nunes MT, et al. (2001) Changes in sodium or glucose filtration rate modulate expression of glucose transporters in renal proximal tubular cells of rat. J Membr Biol 182 : 105-112.

4. Zelikovic I (2004) Aminoaciduria and glycosuria. Pediatric Nephrology In: Avner ED, Harmon WE, Niudet P (eds) Fifth edition Baltimore, Philadelphia, Hong Hong, London, Munich, Sidney, Tokyo: Williams \& Wilkins 718-728.

5. Magen D, Sprecher E, Zelikovic I, Skorecki K (2005) A novel missense mutation in SLC5A2 encoding SGLT2 underlies autosomal-recessive renal glucosuria and aminoaciduria. Kidney Int 67: 34-41.

6. Elsas LJ, Rosenberg LE (1969) Familial renal glycosuria: A genetic reappraisa of hexose transport by kidney and intestine. J Clin Invest 48: 1845-1854

7. Santer R, Kinner M, Schneppenheim R, Hillebrand G, Kemper M, et al. (2000) The molecular basis of renal glucosuria: Mutations in the gene for a renal glucose transporter (SGLT2). J Inherit Metab Dis 23: 178

8. Calado J, Loeffler J, Sakallioglu O, Gok F, Lhotta K, et al. (2006) Familial renal glucosuria: SLC5A2 mutation analysis and evidence of salt-wasting. Kidney Int 69: 852-855.

9. Kleta R, Stuart C, Gill FA, and Gahl WA (2004) Renal glucosuria due to SGLT2 mutations. Mol Genet Metab 82: 56-58.

10. Kloeckener-Gruissem B, Vandekerckhove K, Nürnberg G, Neidhardt J, Zeitz C et al. (2008) Mutation of solute carrier SLC16A12 associates with a syndrome combining juvenile cataract with microcornea and renal glucosuria. Am J Hum Genet 82: 772-779.

11. Santer R, Kinner M, Lassen CL, Schneppenheim R, Eggert P, et al. (2003) Molecular analysis of the SGLT2 gene in patients with renal glucosuria. J Am Soc Nephrol 14: 2873-2882.

12. van den Heuvel LP, Assink K, Willemsen M, Monnens L (2002) Autosomal recessive renal glucosuria attributable to a mutation in the sodium glucose cotransporter (SGLT2). Hum Genet 111: 544-547.

13. Calado J, Sznajer Y, Metzger D, Rita A, Hogan MC, et al. (2008) Twenty-one additional cases of familial renal glucosuria: absence of genetic heterogeneity, high prevalence of private mutations and further evidence of volume depletion, Nephrol Dial Transplant 23: 3874-3879.

14. Hirsch JR, Loo DD, Wright EM (1996) Regulation of Na_/glucose cotransporter expression by protein kinases in Xenopus laevis oocytes. J Biol Chem 271 14740-14746.

15. Fajans SS, Bell GI, Polonsky KS (2001) Molecular mechanisms and Clinica Pathophysiology of Maturity Onset Diabetes of the Young. N Engl J Med 345: 971-980.

16. Hattersley AT, Turner RC, Permutt MA, Patel P, Tanizawa $Y$, et al. (1992) Linkage of type 2 diabetes to the glucokinase gene. Lancet 339: 1307-1310.

17. Frayling TM, Evans JC, Bulman MP, Pearson E, Allen L, et al. (2001) Beta Cell Genes and Diabetes; Molecular and Clinical Characterization of Mutations in Transcription Factors. Diabetes 50: S94-S100.

18. Pontoglio M, Prié D, Cheret C, Doyen A, Leroy C, et al. (2000) HNF1a controls renal glucose reabsorption in mouse and man. EMBO Rep 1: 359-365.

19. Martín MG, Wang J, Solorzano-Vargas RS, Lam JT, Turk E, et al. (2000) Regulation of the human Na+-glucose cotransporter gene SGLT 1 by HNF-1 and Sp1. Am J Physiol Gastrointest Liver Physiol 278: G591-G603.

20. Kekuda R, Saha P, Sundaram U (2008) Role of Sp1 and HNF1 transcription factors in SGLT1 regulation during chronic intestinal inflammation. Am J Physiol Gastrointest Liver Physiol 294: G1354-G1361.

21. Tabatabai NM, Sharma M, Blumenthal SS, Petering DH (2009) Enhanced expressions of sodium-glucose cotransporters in the kidneys of diabetic Zucker rats. Diabetes Res Clin Pract 83: e27-e30.

22. De Marchi S, Cecchin E, Basile A, Proto G, Donadon W, et al. (1984) Close genetic linkage between HLA and renal glycosuria. Am J Nephrol 4: 280-286.

23. Turk E, Wright EM (1997) Membrane topological motifs in the SGLT cotransporter family. J Membr Biol 159: 1-20.

24. Panayotova-Heiermann M, Loo DD, Kong CT, Lever JE, Wright EM (1996) Sugar binding to $\mathrm{Na} /$ glucose cotransporters is determined by the carboxylterminal half of the protein. J Biol Chem 271: 10029-10034.

25. Xie Z, Turk E, Wright EM (2000) Characterization of the Vibrio parahaemolyticus Na1/glucose cotransporter: a bacterial member of the sodiuym/glucose transport (SGLT) family. J Biol Chem 275: 25959-25964. 
Citation: Berdeli A, Nalbantoglu S, Mir S, Ozsan FM, Cam SF, et al. (2010) Novel Nonsense p.C522X Mutation in SLC5A2 Gene of a Turkish Family with Familial Renal Glucosuria: A Molecular Case Report. J Cytol Histol 1:104. doi:10.4172/2157-7099.1000104

Page 6 of 6

26. Panayotova-Heiermann M, Eskandari S, Turk E, Zampighi GA, Wright EM (1997) Five transmembrane helices form the sugar pathway through the $\mathrm{Na}$ glucose cotransporter. J Biol Chem 272: 20324-20327.

27. Panayotova-Heiermann M, Leung DW, Hirayama BA, Wright EM (1999) Purification and functional reconstitution of a truncated human $\mathrm{Na}(+) /$ glucose cotransporter (SGLT1) expressed in E. coli. FEBS Lett 459: 386-390.

28. Wright EM (2001) Renal Na-glucose cotransporters. Am J Physiol Renal Physiol 280: F10-F18.

29. Wright EM (1998) I. Glucose galactose malabsorption. Am J Physiol 275: G879-G882.

30. Steel A, Hediger MA (1998) The Molecular Physiology of Sodium- and ProtonCoupled Solute Transporters. News Physiol Sci 13:123-131.

31. Martín MG, Turk E, Lostao MP, Kerner C, Wright EM (1996) Defects in Na+/ glucose cotransporter (SGLT1) trafficking and function cause glucosegalactose malabsorption. Nat Genet 12: 216-220.

32. Panayotova-Heiermann M, Loo DD, Lostao MP, Wright EM (1994) Sodium/Dglucose cotransporter charge movements involve polar residues. J Biol Chem 269: 21016-21020.

33. Panayotova-Heiermann M, Loo DDF, Wright EM (1995) Pflu gers Arch Eur J Physiol 430: R116.
34. Althoff T, Hentschel H, Luig J, Schütz H, Kasch M, et al. (2006) Na(+)-D-glucose cotransporter in the kidney of Squalus acanthias: molecular identification and intrarenal distribution. Am J Physiol Regul Integr Comp Physiol 290: R1094-R1104.

35. Kasch M (2000) Importance of extracellular cysteines localized the function of the sodium / D-glucose cotransporter (SGLT1). Germany: Heinrich-HeineUniversitat.

36. Wright EM (2001) Renal Na(+)-glucose cotransporters. Am J Physiol Renal Physiol 280: F10-F18.

37. Lostao MP, Hirayama BA, Panayotova-Heiermann M, Sampogna SL, Bok D, et al. (1995) Arginine-427 in the Na+/glucose cotransporter (SGLT1) is involved in trafficking to the plasma membrane. FEBS Lett 377: 181-184.

38. http://coot.embl.de/PolyPhen

39. Zhao FQ, Keating AF (2007) Functional Properties and Genomics of Glucose Transporters. Current Genomics 8: 113-128.

40. Ikari A, Suketa Y (2002) Expression of GFP-tagged low affinity $\mathrm{Na}+$ dependent glucose transporter in Xenopus oocytes and CHO cells. Jpn J Physiol 52: 395398. 